\title{
THE SINS SCALE IN THE EVALUATION OF STABILITY IN PATIENTS WITH SPINAL METASTASIS
}

\author{
A ESCALA SINS NA AVALIAÇÃO DE DOENTES COM METÁSTASE NA COLUNA VERTEBRAL, \\ RELACIONADA À ESTABILIDADE
}

\section{LA ESCALA SINS EN LA EVALUACIÓN DE PACIENTES CON METASTASIS EN LA COLUMNA VERTEBRAL, RELACIONADA A LA ESTABILIDAD}

\author{
Ariel Falbel lugão, ${ }^{1,2}$ Clovis Castanho Silvelra Junior, 1,2 William Gemio Jacobsen Teixeira, ${ }^{1,2}$ Alexandre Fogacta Cristante ${ }^{1,2}$ \\ 1. Universidade de São Paulo, Faculdade de Medicina, Instituto de Ortopedia de Traumatologia, São Paulo, SP, Brazil. \\ 2. Instituto do Câncer do Estado de São Paulo, Department of Spinal Surgery, São Paulo, SP, Brazil.
}

\begin{abstract}
Objective: To evaluate the distribution of patients seen in the emergency care unit of the Instituto do Câncer do Estado de São Paulo in the categories "stable", "indeterminate" and "unstable" as classified by the SINS scale. Methods: The medical charts of patients treated between May and September 2013 were reviewed. Patients with a diagnosis of spinal metastasis were analyzed and data on age, sex, primary tumor location, neurological status, and the presence and intensity of pain at rest and in movement were obtained. The SINS criteria were used to evaluate the radiological involvement of the spine. Results: We included 81 patients with a mean age of 59.57 years; $32(39.51 \%)$ men and $49(60.49 \%)$ women. Breast (19.75\%), prostate (18.52\%) and lung (17.28\%) were the most common primary tumor sites. Only 18 patients (22.22\%) had a single lesion and $51(62.96 \%)$ had 3 or more metastatic lesions. Of the total, $56(69.14 \%)$ were of undetermined stability, 19 were stable (23.46\%) and 6 were unstable (7.41\%). Twenty-two (27.2\%) presented neurological deficit in the physical examination. None of the patients with severe deficit, Frankel A or B, were stable according to the SINS classification. All unstable lesions presented with kyphotic and/or scoliotic deviation ( $p<0.001)$. Most patients with undetermined lesions $(78.6 \%)$ and all patients with unstable lesions had mechanical pain $(p=0.001)$. Conclusion: In this case series, there was a high rate of patients classified by the SINS scale as of undetermined instability (69.14\%). There was a high number of patients with multiple metastases (62.96\%), which was not considered a modifier of the SINS instability criteria and which needs to be the focus of future studies. Level of evidence IV; Case Series.
\end{abstract}

Keywords: Spine; Spinal Neoplasms; Lumbar Vertebrae; Cervical Vertebrae; Low Back Pain; Emergencies.

\section{RESUMO}

Objetivo: Avaliar a distribuição de doentes atendidos no pronto-socorro do Instituto do Câncer do Estado de São Paulo nas categorias "estável", "indeterminada" e "instável" pela escala SINS. Métodos: Levantaram-se prontuários dos doentes atendidos entre maio e setembro de 2013. Foram avaliados os doentes com diagnóstico de metástase vertebral e obtidos dados sobre idade, sexo, localização primária, situação neurológica, presença e intensidade da dor no repouso e no movimento. Os critérios da escala SINS foram utilizados para pontuação do comprometimento radiológico da coluna. Resultados: Foram incluídos 81 doentes com média de idade de 59,57 anos; 32 (39,51\%) homens e 49 (60,49\%) mulheres, sendo que a mama (19,75\%), próstata (18,52\%) e pulmão (17,28\%) foram as localizações primárias mais comuns. Apenas 18 doentes (22,22\%) apresentaram lesão isolada e 51 (62,96\%) apresentaram 3 ou mais lesões metastáticas. Do total, 56 (69,14\%) apresentaram coluna com estabilidade indeterminada; 19 (23,46\%) estável e 6 (7,41\%) instável. Vinte e dois (27,2\%) apresentaram déficit neurológico ao exame físico. Dos doentes com déficit grave, Frankel A ou B, nenhum apresentou coluna estável através da classificação SINS. Todas as lesões instáveis apresentaram-se com desvio cifótico elou escoliótico $(p<0,001)$. A maioria dos pacientes com lesões indeterminadas (78,6\%) apresentou dor de caráter mecânico e todos os pacientes com lesão instável apresentaram dor mecânica ( $p=0,001)$. Conclusões: Nessa série de casos, o uso da escala SINS teve uma taxa elevada de doentes com coluna classificada como indeterminada (69,14\%). Há um número elevado de doentes com metástases múltiplas (62,96\%), fato não considerado pela SINS como modificador nos critérios de instabilidade e que precisa ser alvo de novos estudos. Nível de evidência IV; Serie de casos.

Descritores: Coluna Vertebral; Neoplasias da Coluna Vertebral; Vértebras Lombares; Vértebras Cervicais; Dor Lombar; Emergências.

\section{RESUMEN}

Objetivo: Evaluar la distribución de los enfermos en la unidad de primeros auxilios del Instituto del Cáncer de Estado de São Paulo en las categorías "estable", "indeterminada" e "inestable" por la escala SINS. Métodos: Se levantaron historiales clínicos de los enfermos atendidos entre mayo y septiembre de 2013. Fueron evaluados los enfermos con diagnóstico de metástasis vertebral, y se obtuvieron datos sobre edad, sexo, localización primaria, situación neurológica, presencia e intensidad del dolor en reposo y en movimiento. Los criterios de la escala SINS se utilizaron para puntuación del compromiso radiológico de la columna. Resultados: Fueron incluidos 81 pacientes con promedio de edad de 59,57 años; 32 (39,51\%) hombres y 49 (60,49\%) mujeres, siendo que la mama (19,75\%), próstata (18,52\%) y pulmón (17,28\%) fueron las localizaciones primarias más comunes. Sólo 18 enfermos (22,22\%) presentaron lesión aislada y 51 (62,96\%) presentaron tres o más lesiones metastásicas. Del total, 56 (69,14\%) presentaron columna con estabilidad indeterminada; 19 (23,46\%) estable y 6 estable

Study conducted at the Instituto do Câncer do Estado de São Paulo ICESP - Av. Dr. Arnaldo, 251 - Cerqueira César, São Paulo, SP, Brazil. 01246-000.

Correspondence: Ariel Falbel Lugão. Rua Piaui, 2017, ap 41, Higienópolis, São Paulo, SP, Brasil. 01241-001. arielfl@gmail.com 
(7,41\%) inestable. Veintidós (27,2\%) presentaron déficit neurológico al examen físico. De los enfermos con déficit grave, Frankel A o B, ninguno presentó columna estable a través de la clasificación SINS. Todas las lesiones inestables se presentaron con desviación cifótica y/o escoliótica $(p<0,001)$. La mayoría de los pacientes con lesiones indeterminadas $(78,6 \%)$ presentó dolor de carácter mecánico y todos los pacientes con lesión inestable presentaron dolor mecánico $(p=0,001)$. Conclusiones: En esta serie de casos, el uso de la escala SINS tuvo una tasa elevada de enfermos con columna clasificada como indeterminada (69,14\%). Hay un número elevado de enfermos con metástasis múltiples (62,96\%), hecho no considerado por la SINS como modificador en los criterios de inestabilidad y que necesita ser objeto de nuevos estudios. Nivel de evidencia IV; Serie de casos.

Descriptores: Columna Vertebral; Neoplasias de la Columna Vertebral; Vértebras Lumbares; Vértebras Cervicales; Dolor de la Región Lumbar; Urgencias Médicas.

\section{INTRODUCTION}

Spinal metastases occur frequently in cancer patients. They may be the initial manifestation of the disease in up to $20 \%$ of cases of patients with cancer. ${ }^{1}$ Among the complications from spinal metastasis are compression of the spinal cord, radicular compression, local pain, and mechanical instability. ${ }^{2-4}$

In the presence of medullary compression with motor deficit caused by a solid tumor, the importance of surgical treatment is well established. 2,5-7 Even in the absence of spinal cord compression, spinal instability may require surgical treatment and is a relative contraindication for isolated radiotherapy. Despite the relevance of instability for the indication of surgical treatment, there is controversy around the best method for its diagnosis. ${ }^{8}$ Often, the diagnosis and treatment conduct are made subjectively and depend on the experience of the surgeon. ${ }^{7}$

The Spine Oncology Study Group (SOSG) defines instability as the loss of spinal integrity resulting from a neoplastic process that is associated with movement-related pain, symptomatic or progressive deformity, and/or neurological impairment under physiological loads. ${ }^{9}$ In that same article, in 2010, they published a scale called the Spine Instability Neoplastic Score (SINS), based on the best information published in the literature and the opinions of experts, aimed at improving the quality of instability diagnoses.

One of the possible applications of the SINS scale would be to assist in the screening and diagnosis of instability in patients with spinal metastasis in urgent care and emergency units so that unstable patients and those with undetermined instability could be evaluated by a specialized team to determine the definitive treatment. ${ }^{10,11}$ However, there are currently no data in our area of interest that show the distribution of cases categorized by the SINS scale as stable, undetermined, or unstable. Nor have any studies been identified in the international literature that present similar data.

The objective of this study is to retrospectively evaluate the distribution of patients by stability as classified according to the SINS scale by the on call orthopedics team in an emergency unit specialized in oncology.

\section{METHODS}

We reviewed the medical records of patients seen by spine specialists at the Centro de Atendimento de Intercorrências Oncológicas (CAIO) of the Instituto do Câncer do Estado de São Paulo (ICESP) from May to September of 2013. All patients diagnosed with spinal metastasis attended by the interdisciplinary consultation team of the Spine Group were included.

The study was approved by the Institutional Review Board as protocol number 35684614.0.0000.0065.

Cases without tomography or simple radiography, which prevents the evaluation of the quality of the bone matrix, cases with incomplete medical record data, which prevents characterization of pain quality, and cases with complaints unrelated to metastatic disease were excluded

Data about age, sex, site of the primary tumor, neurological status according to the Frankel scale, presence and intensity of pain at rest and in movement as evaluated by the visual analog scale were obtained.
We classified pain in movement that was at least two points higher than pain at rest, as scored on the visual analog scale for pain, as mechanical pain.

The location of the lesion, bone matrix quality, spinal alignment, presence of vertebral body collapse, and involvement of the posterior elements were evaluated by computed tomography or magnetic resonance associated with simple radiography, when necessary. In cases with multiple spinal lesions, the most serious lesion was used.

The SINS classification uses parameters such as the location of the lesion, clinical pain characteristics, quality of the matrix of the bone lesion, radiographic alignment of the spine, presence of collapse of the vertebral body, and involvement of the structures of the posterior spine. The minimum score is 0 and the maximum is 18 points $^{9}$. (Table 1)

To confirm the associations of the primary tumor, bone matrix, vertebral involvement, posterolateral involvement, and strength level, the Chi-square test was used, and Fisher's exact test was used for vertebral location, vertebral alignment, and pain quality. The confidence interval established was $95 \%$ and $p$ was considered significant if $<0.05$.

Table 1. SINS Classification. ${ }^{9}$

\begin{tabular}{|c|c|}
\hline & Score \\
\hline \multicolumn{2}{|l|}{ Location } \\
\hline Junctional (Occiput-C2, C7-T2, T11-L1, L5-S1) & 3 \\
\hline Mobile Spine (C3-C6, L2-L4) & 2 \\
\hline Semi-rigid (T3-T10) & 1 \\
\hline Rigid (S2-S5) & 0 \\
\hline \multicolumn{2}{|l|}{ Mechanical or Postural Pain } \\
\hline Yes & 3 \\
\hline No (occasional, but non-mechanical) & 1 \\
\hline Lesion without pain & 0 \\
\hline \multicolumn{2}{|l|}{ Bone quality of the lesion } \\
\hline Lytic & 2 \\
\hline Mixed (lytic/blastic) & 1 \\
\hline Blastic & 0 \\
\hline \multicolumn{2}{|l|}{ Spinal alignment } \\
\hline Subluxation/translation & 4 \\
\hline New deformity (kyphosis/scoliosis) & 2 \\
\hline Normal alignment & 0 \\
\hline \multicolumn{2}{|l|}{ Vertebral body involvement } \\
\hline$>50 \%$ collapse & 3 \\
\hline$<50 \%$ collapse & 2 \\
\hline Without collapse - $50 \%$ of body involved & 1 \\
\hline None of the above & 0 \\
\hline \multicolumn{2}{|l|}{ Posterior involvement } \\
\hline Bilateral & 3 \\
\hline Unilateral & 1 \\
\hline None of the above & 0 \\
\hline
\end{tabular}




\section{RESULTS}

One hundred and three patients were treated by the Spine Group during the period from May 1 to September 30 of 2013. Twenty-two patients were excluded; 12 for lack of information that would allow the interpretation of pain quality, 8 due to the absence of metastasis in the imaging examinations, one who had meningeal carcinomatosis without bone damage, and one who died before the imaging examinations were performed.

Eighty-one patients with a mean age of 59.57 years (28.71-79.32) were included, 32 of whom $(39.51 \%)$ were male and 49 of whom $(60.49 \%)$ were female. Breast (19.75\%), prostate (18.52\%), and lung (17.28\%) were the most common primary tumor sites. The distribution of patients by tumor location is described in Table 2.

Fifty-one patients $(62.96 \%)$ had three or more metastatic lesions. Only 18 patients (22.22\%) had a single lesion. (Table 3 )

Of the total number of patients seen, the spinal stability was undetermined in 56 (69.14\%), stable in 19 (23.46\%), and unstable in $6(7.41 \%)$. (Table 4$)$

Fifty-nine patients (72.8\%) presented no neurological deficit in the physical examination. Of these patients, 14 (17.38\%) had a

Table 2. Distribution of patients by primary tumor location.

\begin{tabular}{c|c|c}
\hline Location of the primary tumor & Number of cases & $\%$ \\
\hline Breast & 16 & $19.75 \%$ \\
\hline Prostate & 15 & $18.52 \%$ \\
\hline Lung & 14 & $17.28 \%$ \\
\hline Kidney & 7 & $8.64 \%$ \\
\hline Colorectal & 6 & $7.41 \%$ \\
\hline Multiple myeloma & 6 & $7.41 \%$ \\
\hline Musculoskeletal & 4 & $4.94 \%$ \\
\hline Unknown & 3 & $3.70 \%$ \\
\hline Esophagus & 3 & $3.70 \%$ \\
\hline Lymphoma & 2 & $2.47 \%$ \\
\hline Trachea & 1 & $1.23 \%$ \\
\hline Thyroid & 1 & $1.23 \%$ \\
\hline Cervix & 1 & $1.23 \%$ \\
\hline Unknown primary & 1 & $1.23 \%$ \\
\hline Stomach & 1 & $1.23 \%$ \\
\hline Overall Total & 81 & $100.00 \%$ \\
\hline
\end{tabular}

Table 3. Distribution of patients by site of primary tumor and number of spinal metastases.

\begin{tabular}{c|c|c|c|c}
\hline & & \multicolumn{2}{|c|}{$\begin{array}{c}\text { Number of spinal } \\
\text { metastases }\end{array}$} & \\
\hline Location of the primary tumor & One & Two & $\mathbf{3}$ or more & Overall Total \\
\hline Breast & 2 & 1 & 13 & 16 \\
\hline Prostate & 2 & 2 & 11 & 15 \\
\hline Lung & 4 & 1 & 9 & 14 \\
\hline Kidney & 4 & 1 & 2 & 7 \\
\hline Colorectal & 2 & 2 & 2 & 6 \\
\hline Multiple myeloma & 1 & 1 & 4 & 6 \\
\hline Musculoskeletal & 1 & 1 & 2 & 4 \\
\hline Esophagus & 1 & 2 & 0 & 3 \\
\hline Unknown & 0 & 1 & 2 & 3 \\
\hline Lymphoma & 0 & 0 & 2 & 2 \\
\hline Unknown primary & 0 & 0 & 1 & 1 \\
\hline Cervix & 1 & 0 & 0 & 1 \\
\hline Trachea & 0 & 0 & 1 & 1 \\
\hline Thyroid & 0 & 0 & 1 & 1 \\
\hline Stomach & 0 & 0 & 1 & 1 \\
\hline Overall Total & 18 & 12 & 51 & 81 \\
\hline
\end{tabular}

stable spine and 41 (51.8\%) had undetermined spinal stability. None of the patients with severe neurological deficit, Frankel A or B, had a stable spine as classified by SINS score (Table 5).

Mean pain at rest and in movement by SINS classification are shown in Table 5. We obtained the following data: the 19 patients (23\%) with stable spines had a mean VAS score of 0.68 at rest and 1.95 in movement; the 56 patients (69\%) classified as undetermined had a mean VAS of 1.3 at rest and 5.2 in movement; and in the 6 patients $(7.4 \%)$ with the unstable spine classification, the mean VAS at rest was 2.33 and in movement was 6.33 (Table 6).

Regarding alignment, all the unstable lesions presented kyphotic and/or scoliotic deviation $(p<0.001)$. However, in the cases with undetermined stability, only a small percentage (7.1\%) were kyphotic or scoliotic $(p=0.043)$, and none $(0 \%)$ of the stable patients had a new deformity $(p<0.001)$. (Table 6$)$

As for the location, $76.8 \%$ of the undetermined lesions were in the mobile spine or junctional segments $(p=0.01)$. All the lesions in the rigid spine were stable. We found no statistically significant association in our comparison of the location and instability of the unstable lesions. (Table 7)

Table 4. Distribution of stability according to the SINS scale by primary tumor location.

\begin{tabular}{c|c|c|c|c}
\hline & & $\begin{array}{c}\text { Instability } \\
\text { according to SINS }\end{array}$ & & \\
\hline $\begin{array}{c}\text { Location of the } \\
\text { primary tumor }\end{array}$ & Stable & Undetermined & Unstable & $\begin{array}{c}\text { Overall } \\
\text { Total }\end{array}$ \\
\hline Breast & 1 & 13 & 2 & 16 \\
\hline Prostate & 5 & 10 & 0 & 15 \\
\hline Lung & 5 & 9 & 0 & 14 \\
\hline Kidney & 1 & 5 & 1 & 7 \\
\hline Colorectal & 3 & 3 & 0 & 6 \\
\hline Multiple myeloma & 1 & 4 & 1 & 6 \\
\hline Musculoskeletal & 2 & 2 & 0 & 4 \\
\hline Esophagus & 1 & 2 & 0 & 3 \\
\hline Unknown & 0 & 3 & 0 & 3 \\
\hline Lymphoma & 0 & 2 & 0 & 2 \\
\hline Unknown primary & 0 & 0 & 1 & 1 \\
\hline Cervix & 0 & 0 & 1 & 1 \\
\hline Trachea & 0 & 1 & 0 & 1 \\
\hline Thyroid & 0 & 1 & 0 & 1 \\
\hline Stomach & 0 & 1 & 0 & 1 \\
\hline Overall Total & 19 & 56 & 6 & 81 \\
\hline & & & &
\end{tabular}

Table 5. Distribution of patients by neurological status as defined by the Frankel scale and by instability according to the SINS scale.

\begin{tabular}{c|c|c|c|c}
\hline & \multicolumn{3}{|c|}{ Instability according to SINS } & \\
\hline Frankel & Stable & Undetermined & Unstable & Overall Total \\
\hline A+B & 0 & 5 & 2 & 7 \\
\hline C+D & 5 & 9 & 1 & 15 \\
\hline E & 14 & 42 & 3 & 59 \\
\hline Overall Total & 19 & 56 & 6 & 81 \\
\hline \multicolumn{5}{|c}{}
\end{tabular}

Table 6. Distribution of patients by verbal response (VAS) to pain and by instability as defined by the SINS scale.

\begin{tabular}{c|c|c|c}
\hline $\begin{array}{c}\text { Instability according } \\
\text { to SINS }\end{array}$ & $\begin{array}{c}\text { Number of } \\
\text { cases }\end{array}$ & $\begin{array}{c}\text { Mean VAS at } \\
\text { rest }\end{array}$ & $\begin{array}{c}\text { Mean VAS in } \\
\text { movement }\end{array}$ \\
\hline Stable & 19 & $0.68 \pm 1.82$ & $1.95 \pm 3.24$ \\
\hline Undetermined & 56 & $1.30 \pm 1.88$ & $5.20 \pm 3.05$ \\
\hline Unstable & 6 & $2.33 \pm 3.67$ & $6.33 \pm 3.72$ \\
\hline
\end{tabular}


Table 7. Distribution of patients by vertebral alignment, vertebral location, vertebral collapse, posterolateral lesion, and Frankel scale.

\begin{tabular}{|c|c|c|c|}
\hline & Stable & Undetermined & Unstable \\
\hline \multicolumn{4}{|c|}{ Location of the primary tumor } \\
\hline Breast $(p=0.162)$ & 1 & 13 & 2 \\
\hline Prostate $(p=0.342)$ & 5 & 10 & 0 \\
\hline Lung $(p=0.302)$ & 5 & 9 & 0 \\
\hline \multicolumn{4}{|c|}{ Vertebral alignment } \\
\hline Scoliosis/Kyphosis & 0 & $4(7.1 \%)$ & $81(100 \%)$ \\
\hline Normal & $19(100 \%)$ & $52(92.9 \%)$ & 0 \\
\hline$p$ value & 0.106 & $<0.01$ & 0.033 \\
\hline \multicolumn{4}{|c|}{ Vertebral location } \\
\hline Rigid & $4(21.1 \%)$ & 0 & 0 \\
\hline Semi-rigid & $6(31.6 \%)$ & $13(23.2 \%)$ & $2(33.3 \%)$ \\
\hline Mobile & $7(36.8 \%)$ & $23(41.1 \%)$ & $2(33.3 \%)$ \\
\hline Junctional & $2(10.5 \%)$ & $20(35.7 \%)$ & $2(33.3 \%)$ \\
\hline$p$ value & $<0.01$ & 0.908 & $<0.01$ \\
\hline \multicolumn{4}{|c|}{ Bone matrix } \\
\hline Blastic & $6(31.6 \%)$ & $8(14.3 \%)$ & 0 \\
\hline Mixed & $6(31.6 \%)$ & $22(39.3 \%)$ & $2(33.3 \%)$ \\
\hline Lytic & $7(36.8 \%)$ & $26(46.4 \%)$ & $4(66.7 \%)$ \\
\hline$p$ value & \multicolumn{3}{|c|}{0.315} \\
\hline \multicolumn{4}{|c|}{ Vertebral collapse } \\
\hline $\begin{array}{c}\text { Without collapse } \\
>50 \% \text { involvement }\end{array}$ & $10(32.3 \%)$ & $21(37.5 \%)$ & 0 \\
\hline Collapse $<50 \%$ & $1(5 \%)$ & 19(33.9\%) & 0 \\
\hline Collapse $>50 \%$ & 0 & $7(12.5 \%)$ & $6(100 \%)$ \\
\hline Without involvement & $8(47.1 \%)$ & $9(16.1 \%)$ & 0 \\
\hline$p$ value & \multicolumn{3}{|c|}{$<0.01$} \\
\hline \multicolumn{4}{|c|}{ Posterolateral } \\
\hline Unilateral & $7(36.8 \%)$ & $18(32.1 \%)$ & $2(33.3 \%)$ \\
\hline Bilateral & $2(10.5 \%)$ & $29(51.8 \%)$ & $4(66.7 \%)$ \\
\hline Without involvement & $10(52.6 \%)$ & $9(16.1 \%)$ & 0 \\
\hline$p$ value & \multicolumn{3}{|c|}{$<0.01$} \\
\hline \multicolumn{4}{|c|}{ Frankel } \\
\hline$A+B$ & 0 & $5(9.1 \%)$ & $2(33.3 \%)$ \\
\hline$C+D$ & $4(23.5 \%)$ & $8(14.5 \%)$ & $1(16.7 \%)$ \\
\hline$E$ & $13(76.5 \%)$ & $42(76.4 \%)$ & $3(50 \%)$ \\
\hline$p$ value & 0.276 & 0.738 & 0.09 \\
\hline \multicolumn{4}{|c|}{ Pain quality } \\
\hline Without pain & $11(57.8 \%)$ & $5(8.9 \%)$ & 0 \\
\hline Local & $4(21.1 \%)$ & $7(12.5 \%)$ & 0 \\
\hline Mechanical & $4(21.1 \%)$ & $44(78.6)$ & $6(100 \%)$ \\
\hline$p$ value & \multicolumn{3}{|c|}{$<0.01$} \\
\hline
\end{tabular}

\section{DISCUSSION}

Medullary compression can occur due to several factors. It can result from the growth of tumor epidural mass with direct compression of the spinal cord, from the compression of bone fragments of a pathological fracture, or from vertebral deformity or instability. ${ }^{3}$ The role of surgery for the treatment of symptomatic metastatic medullary compression is established ${ }^{2}$ and contributes to improved quality of life and maintenance of the patients' ability to walk. ${ }^{12}$ Vertebral instability is also an indication for surgical treatment, even if there is no medullary compression, ${ }^{13-15}$ but diagnostic criteria are still controversial.

Application of the SINS scale is recommended as a tool for tracking instability

According to Arana et al., the SINS score had moderate to excellent intra- and interobserver concordance in an evaluation performed only by non-specialists, making it an effective tool for communication between specialties. ${ }^{10}$ Versteeg et al. retrospectively compared the surgical or radiotherapeutic outcomes in patients before and after the use of SINS by oncologists and noted more rapid and efficient referencing following use of the score. ${ }^{16}$

In the emergency room, in the absence of neurological signs and symptoms patients with a stable spine could be referred for elective follow-up. Patients with scores greater than or equal to seven $^{9}$ should be evaluated by a specialist to determine if there is a need to institute early treatment before any complications, such as deformity or neurological deficit, occur.

In this study, $69.14 \%$ of the cases were classified as of undetermined stability and $7.41 \%$ as unstable. Thus, few patients could have been exempted from the specialist's evaluation. The largest subgroup of patients evaluated was that classified as undetermined instability, a situation in which the experience of the specialist is still necessary for a subjective assessment of the conduct to be followed. Currently, prospective clinical studies that evaluate the outcome of this subgroup of patients over time are lacking.

Most of the cases (77.78\%) had more than one spinal lesion. Three or more lesions were identified in $62.96 \%$ of the patients. Eventually, the presence of lesions in adjacent vertebrae could increase the risk of mechanical complications. There are no modifiers for multiple spinal lesions in the SINS scale.

In our case series, metastases from breast, prostate, and lung tumors predominated. These data are in accordance with the high frequency of these neoplasms in the overall population and also with the frequency of bone metastases. ${ }^{2,17,18}$ It was expected that metastatic tumors usually associated with lytic lesions, such as a metastatic lung tumor, would have a higher frequency of instability than those with blastic lesions, such as metastatic prostate tumors. However, there was no association between the histological type and the presence of instability in our sample when we evaluated the three most common primary tumors: breast $(p=0.162)$, prostate $(p=0.342)$, and lung $(p=0.302)$. The lack of association may be caused by the low representation of each histological type in a study with a great heterogeneity of diagnoses.

Fifty-nine $(72.8 \%)$ of the patients attended did not present neurological deficit. Considering that the presence of neurological deficit would already indicate the need for specialized evaluation, the group of patients without deficit is the group where the SINS scale would have the greatest impact on screening patients at risk for instability. Only $17.38 \%$ of the patients without deficit were judged to have stable spines and could theoretically be discharged without being assessed by a specialist. None of the patients with severe deficit, Frankel A or B, had their spine classified as stable. This fact reinforces instability as a severity factor.

Regarding painful symptoms, there was a correlation between pain intensity and more serious levels of instability, either at rest or in movement. In stable lesions, $57.8 \%$ of the patients did not complain about pain. Most patients with undetermined lesions (78,6\%) and all patients with unstable lesions had mechanical pain $(p=0.001)$. Thus, there is a relationship between pain and instability, as already determined in other studies. ${ }^{12,14,15,19}$

Kyphotic or scoliotic alignment disorders were present in all cases of spines defined as unstable, indicating an important relationship between alignment and instability. Stable spines did not present deformity in the sagittal or coronal planes.

In this study, lesions located in the sacrum were all stable. It is known that the risk of instability increases in the junctional regions and mobile spine. ${ }^{9}$ Thus, lesions characterized as undetermined were more often found in these regions. The absence of a statistical relationship between spinal instability and the location of the lesion is probably due to the small number of unstable lesions in this sample.

When we evaluated the quality of the bone matrix, none of the blastic lesions were found to be unstable, while the lytic lesions were unstable in two thirds of the cases. The absence of statistical correlation may be related to the small number of unstable lesions in the sample. In this study, only one observer judged matrix quality. 
It is known that the quality of the bone matrix is a factor of weaker interobserver concordance in the SINS ${ }^{20,21}$ so there may have been inaccuracy in judgment of the matrix quality.

The assessment of vertebral body impairment in this study showed an expected correlation between the progression of vertebral body collapse and instability, where all the unstable lesions had significant body collapse and the undetermined lesions were almost exclusively restricted to lesions with less than 50\% collapse. In our study, posterolateral involvement was more frequent in the unstable cases grouped with those of undetermined stability when compared to cases with stable spines. The findings of Shi et al. ${ }^{21}$ reinforce the thesis of progressive collapse, but their study focused on the outcome following radiotherapy. Of the patients with spinal metastasis submitted to radiotherapy, $20.4 \%$ presented progression of collapse and $50 \%$ of these were classified as unstable on the SINS scale. ${ }^{21}$

\section{CONCLUSION}

In this case series, use of the SINS scale in the urgent care environment for cancer patients yielded a high rate of patients with spines classified as undetermined (69.14\%), so that in most cases the judgment of stability would still depend on the opinion of a specialist. There is also a high number of patients with multiple metastases $(62.96 \%)$, a factor not considered by SINS as a modifier of the instability criteria and that needs to be the focus of future studies.

Prospective studies that take the clinical outcome into account are fundamental to understanding the importance of the SINS scale in clinical practice.

All authors declare no potential conflict of interest related to this article.

CONTRIBUTION OF THE AUTHORS: Each author made significant individual contributions to this manuscript. AFL: Data collection, writing, statistical analysis, review. CCSJ: Data collection, statistical analysis, review. WGJT: Writing, statistical analysis, review. AFC: Statistical analysis, review.

\section{REFERENCES}

1. Schiff D, O'Neill BP, Suman VJ. Spinal epidural metastasis as the initial manifestation of malignancy: clinical features and diagnostic approach. Neurology. 1997;49(2):452-6.

2. Patchell RA, Tibbs PA, Regine WF, Payne R, Saris S, Kryscio RJ, et al. Direct decompressive surgical resection in the treatment of spinal cord compression caused by metastatic cancer: a randomised trial. Lancet. 2005:366(9486):643-8.

3. Constans JP, Divitiis E de, Donzelli R, Spaziante R, Meder JF, Haye C. Spinal metastases with neurological manifestations. Review of 600 cases. J Neurosurg. 1983;59(1):111-8.

4. Araujo JLV, Veiga JCE, Figueiredo EG, Barboza VR, Daniel JW, Panagopoulos AT. Manejo das neoplasias metastáticas da coluna vertebral - uma atualização. Rev Col Bras Cir. 2013:40(6):508-14.

5. Fisher CG, Andersson GBJ, Weinstein JN. Spine Focus Issue Summary of Management Recommendations in Spine Oncology. Spine (Phila Pa 1976). 2009;34(22):2-6.

6. Bilsky MH, Laufer I, Burch S. Shifting paradigms in the treatment of metastatic spine disease. Spine (Phila Pa 1976). 2009;34(22 Suppl):S101-7.

7. Borges PA, Teixeira WGJ, Narazaki DK, Cristante AF, Ghilardi CS, Teixeira MJ, et al. Laminectomy without instrumentation for surgical treatment of metastatic spinal cord compression. Coluna/Columna. 2014;13(1):63-6.

8. Weber MH, Burch S, Buckley J, Schmidt MH, Fehlings MG, Vrionis FD, et al. Instability and impending instability of the thoracolumbar spine in patients with spinal metastases: a systematic review. Int J Oncol. 2011;38(1):5-12.

9. Fisher CG, DiPaola CP, Ryken TC, Bilsky MH, Shaffrey Cl, Berven SH, et al. A novel classification system for spinal instability in neoplastic disease: an evidence-based approach and expert consensus from the Spine Oncology Study Group. Spine (Phila Pa 1976). 2010;35(22):E1221-9

10. Arana E, Kovacs FM, Royuela A, Asenjo B, Pérez-Ramírez Ú, Zamora J, et al. Spinal instability neoplasic score: agreement across different medical and surgical specialties. Spine J. 2016;16(5):591-9.

11. Versteeg AL, Van Der Velden JM, Verkoojjen HM, van Vulpen M, Oner FC, Fisher CG, et al. The effect of introducing the spinal instability neoplasic score in routine clinical practice for patients with spinal metastases. Oncologist. 2016;21(1):95-101.

12. Falicov A, Fisher CG, Sparkes J, Boyd MC, Wing PC, Dvorak MF. Impact of surgical intervention on quality of life in patients with spinal metastases. Spine (Phila Pa 1976). 2006:31(24):2849-56.

13. Thomas KC, Nosyk B, Fisher CG, Dvorak M, Patchell RA, Regine WF, et al. Cost-effectiveness of surgery plus radiotherapy versus radiotherapy alone for metastatic epidural spinal cord compression. Int J Radiat Oncol Biol Phys. 2006:66(4):1212-8.

14. Vaccaro AR, Fisher CG, Prasad SK, Patel AA, Chi J, Mulpuri K, et al. Evidence-Based Recommendations for Spine Surgery. Spine (Phila Pa 1976). 2016;41(3):E165-73.

15. Fisher CG, Keynan O, Ondra S, Gokaslan Z. Introduction to Focus Issue in Spine Oncology The Synthesis of Evidence and Expert Opinion for Best Practice Recommendation. Spine (Phila Pa 1976). 2009;34(22):21-5.

16. Fourney DR, Frangou EM, Ryken TC, Dipaola CP, Shaffrey Cl, Berven SH, et al. Spinal instability neoplastic score: an analysis of reliability and validity from the spine oncology study group. J Clin Oncol. 2011;29(22):3072-7.

17. Tofe AJ, Francis MD, Harvey WJ. Correlation of neoplasms with incidence and localization of skeletal metastases: An analysis of 1,355 diphosphonate bone scans. J Nucl Med. 1975;16(11):986-9.

18. Quraishi NA, Gokaslan ZL, Boriani S. The surgical management of metastatic epidural compression of the spinal cord. J Bone Joint Surg Br. 2010;92(8):1054-60.

19. Sciubba DM, Petteys RJ, Dekutoski MB, Fisher CG, Fehlings MG, Ondra SL, et al. Diagnosis and management of metastatic spine disease. J Neurosurg Spine. 2010;13(1):94-108.

20. Teixeira WGJ, Coutinho PRM, Marchese LD, Narazaki DK, Cristante AF, Teixeira MJ, et al. Interobserver agreement for the spine instability neoplastic score varies according to the experience of the evaluator. Clinics (Sao Paulo). 2013:68(2):213-8.

21. Shi DD, Hertan LM, Lam TC, Skamene S, Chi JH, Groff M, et al. Assessing the utility of the spinal instability neoplasic score (SINS) to predict fracture after conventional radiation therapy (RT) for spinal metastases. Pract Radiat Oncol. 2018;8(5):e285-94. 